\title{
İle-İfe: Geleneksel Yoruba Dininde Yaratılışın ve Dünyanın Merkezi
}

\begin{abstract}
Canan Seyfeli*
Atıf/C: Seyfeli, Canan, İle-İfe: Geleneksel Yoruba Dininde Yaratılışın ve Dünyanın Merkezi, Artuklu Akademi 2019/6 (2), 229-252.

Öz: Makalenin konusu, Geleneksel Yoruba Dininde yaratılışın ve dünyanın merkezi kabul edilen İle-İfe' dir. Konu inançsal ve uygulama, mitolojik ve insan yaşamı boyutlarıyla işlenmiştir. Mitolojiye göre İle-İfe yaratılışın, insanlığın (Yorubaların) ve kutsal krallığın beşiğidir. Gök, yer ve yeraltının birleştiği eksendir. Bu eksen Orişaların diktiği Hayat Ağacıdır. Göklerin yere, yeryüzünün göklere açılan kapısı bu eksendedir. Evrenin ve insanın yaratılışının başladığı nokta İle-İfe'nin merkezidir. Burası şimdi sarayın ve tapınağın bulunduğu yerdir. İle-İfe farklı Yoruba yaratılış mitlerinde ortak unsurlardan birisidir. Yorubalara göre tanrısal alemden inip yeryüzünde krallığını kuran Oduduva atasal Orişaya dönüşmüş ilk ata ve kraldır, İle-İfe merkezli en etkili Orişadır. Obatala yaratılışta rol oynasa da etkisi ikinci derecededir. İle-İfe, Olodumare'ye tek somut tapınım yeridir. Merkezde Oduduva'nınki ve etrafında diğer Orişaların tapınakları bulunur. Şehirde çok çeşitli festivaller, ritüeller, sunular icra edilir. Burası bütün yolların kendisine çıktığı dünyanın merkezidir. İle-İfe, Yoruba kültür ve sanat merkezidir.
\end{abstract}

Anahtar Kelimeler: Geleneksel Yoruba Dini, İle-İfe, Merkez Simgeciliği, Yaratılış, Oduduva

\section{Ile-Ife: The Center of Creation and the World in Traditional Yoruba Religion \\ Citation/@: Seyfeli, Canan, Ile-Ife: The Center of Creation and the World in Traditional Yoruba Religion, Artuklu Akademi 2019/6 (2), 229-252.}

\begin{abstract}
The subject of this article is Ile-Ife, namely the centre of creation and the world in the Yoruba religion. In mythology, Ile-Ife is the cradle of the earth, of the Yorubas and the kingdom, and the gate of the heavens to the earth and the earth to the heavens. The Tree of Ile-Ife planted by the Orishas is the axis that connects the sky, the earth and the underworld. The centre of this axis is the IfaVara, the royal palace. Oduduva, the first progenitor and also the first king, is both primordial and ancestral to Orisha. He is the most influential Orisha in IleIfe. On the other hand, Obatala, which takes part in the creation of human being,
\end{abstract}

* Prof. Dr., Dicle Üniversitesi İlahiyat Fakültesi Dinler Tarihi Anabilim Dalı, cseyfeli@yahoo.com. Bu makalenin konusunu bizimle tartışan ve kaynak önerisinde bulunan Elif Kul'a teşekkür ederim. 
is in the second status. Ile-Ife is the only place where Olodumare is the only concrete ritual. The temple of Oduduva is at the centre of the other Orisha temples. In addition to this, Ile-Ife is also in the centre of festivals, rituals, presentations, including Yoruba culture and art.

Keywords: Traditional Yoruba Religion, Ile-Ife, Center Symbolism, Creation, Oduduwa

[The Extended Abstract is at the end of the article.]

\section{Giriş}

Geleneksel Yoruba Kabilesinin kadim bir kenti olan İle-İfe, Nijerya'nın liman şehri Lagos'a 200 km uzaklıkta ve yaklaşık 330 bin nüfuslu bir yerleşim yeridir. Yoruba kasaba ve şehir adlarında yoğun şekilde yer alan "İle" kelimesi genellikle ev, yurt veya toprak ve yer anlamıla kullanılmaktadır. $\mathrm{Bu}$ kelimenin "son dinlenme yeri" anlamı da vardır. Bu bağlamda cenaze töreniyle eve gitmek, atalara katılmak ve asıl ikametgâha dönmek manasındadır. ${ }^{1} \mathrm{Bu}$ mana İle-İfe' nin merkez, göklere açılan kapı olmasıyla alakalıdır. İle-İfe'nin anlamlarından bir diğeriyse "yeryüzüne yayılan" demektir. ${ }^{2} \mathrm{Bu}$ anlam ise merkez ve merkezden insanlığın yayılmasıyla 230 ilişkilidir.

Nijerya ve Benin gibi ülkelerde yaşayan ve Afrika'nın en büyük nüfuslu geleneksel kabilelerinden birisi olan Yorubalar için İle-İfe (İfe, İllife, İffie, İfe, Ufe, Uhe veya İse), dini ve manevi bir merkezdir. İle-İfe, aynı zamanda bir kasabanın, bölgenin ve krallı̆ın da ismidir. ${ }^{3}$ Bu şehir, Afrika sanat ve kültürünün üstün başarılarını da barındırmaktadır. Bugün Batı Afrika'nın güçlü, kozmopolit ve zengin bir yerleşim yeri olan İle-İfe, XII.-XV. yüzyıllarda bir şehir devleti olarak gelişmiştir. Tapınakları ve bahçelerinin hala kullanıldığı, primordiyal (başlangıçta var olan, yaratılışta rol oynayan) Orişalara (tanrısal âlemin tanrısal varlıkları) ritüel uygulamaların yapıldığı İle-İfe, bugün Yorubalar için önemini ve merkezîliğini sürdürmektedir. ${ }^{4}$

Çalışmanın konusu İle-İfe'nin dini merkez olma özelliğidir. Konu mitolojide ve Yoruba yaşam alanında iki yönüyle ele alınmıştır. İki yönlü

\footnotetext{
Jacob K. Olupona, City of 201 Gods: Ilé-Ifê in Time, Space, and the Imagination, (Los Angeles: University of California Press, 2011), 35.

2 Michael O. Anda, Yoruba, (New York: Rosen Pub. Group, 1996), 17.

3 Ade Obayemi, "Ancient Ile-Ife: Another Cultural Historical Reinterpretation", Journal of the Historical Society of Nigeria 9, sy. 4 (1979): 152.

4 Khan Academy, "Kingdom of Ife: Sculptures from West Africa", erişim: 15 Ekim 2019, https://www.khanacademy.org/humanities/art-africa/west-africa/nigeria/a/kingdom-of-ifesculptures-from-west-africa.
} 
inceleme nedeni mitolojiye dayalı bir kabile dini olan Geleneksel Yoruba Dini'nin insan yaşamına yansıdığı alanda mitolojiyle içkin bir duruş sergilemesidir. Mitoloji ve diğer sözlü geleneğin ürünleriyle İle-İfe'de gerçekleşen faaliyetler karşılaştırıldığında mit ile yaşamın birbiriyle örtüştüğü görülmüştür. Yoruba yaşamının mitolojinin bir uyarlaması olması, Eliade' ın "mitler ancak gerçek olanı anlatır" ${ }^{5}$ sözünün açık örneğidir. Gerçek olduğuna inanılan mit yaşamı biçimlendirmektedir. Yaratılışın gerçekleştiği yer olan İle-İfe yaşamın da merkezi olmuştur. Bu merkez gök ile yeri, görünen âlemle görünmeyen âlemi, Orişalarla ve Yüce Tanrı Olodumare' yle insanları bir araya getirmektedir. İle-İfe, insanın kutsallaştığı kutsal şehirdir. Çalışmanın amacı bu birleşmenin ve dönüşmenin mitoloji ve yaşamdaki gerçekliğini ortaya koymak, böylece İle-İfe'nin hangi özellikleriyle merkezi konumda olduğunu açı̆̆a çıkarmaktır.

İle-İfe'nin Geleneksel Yoruba dininde yaratılışın ve dünyanın merkezi kabul edilmesinin mitolojiye dayalı bazı nedenleri vardır. Birincisi, evrenin ve insanın yaratılışında başlangıç noktası olmasıdır. Mitolojide, yaratılışta Yüce Tanrı Olodumare' nin verdiği görevlerle Orişa adı verilen tanrısal varlıkların insan yaşamına uygun olarak yeryüzünü düzenlediklerinde İle-İfe başlangıç noktasıdır. Aynı zamanda bu noktanın etrafında şekillenen yerleşim yeridir. ${ }^{6}$ Başlangıçta primordiyal su ve basit bir toprak iken Orişaların başlattığı dünyanın ve insanın yaratılışıyla kutsal İle-İfe' ye dönüşmüştür.

İkincisi; İle-İfe, kutsal Orişaların yeryüzünde ayak bastıkları ilk yerdir. Olodumare'nin görevlendirmesiyle göklerin kapısından yeryüzüne inen Orişalar bu noktada görevlerini icraya başlamışlardır. Bazı mitlerde iniş altın zincirledir. Zincirin sarktığı yer yaratılışın başlangıç noktası İle-İfe' dir. Bu, İleİfe'nin yerin göklere açılan kapısı olmasıyla alakalıdır. Bu kapı, göklerin yeryüzüne açılan kapısıyla aynı eksendedir. Gök ile yerin birleştiği eksende görev yapan Orişalar hem göksel hem de yersel özelliklere sahiplerdir. Orişaların aracılık özellikleriyle yerleştikleri İle-İfe, insanoğlunun ve dünya hayatının da başlangıç noktasıdır. ${ }^{7}$

Üçüncüsü; İle-İfe, hem primordiyal hem de Yorubaların atası kabul edilen, yani atasal Orişa olan Oduduva'nın (Odudua: denetleyici ve kral olan tanrısal varlık) soyundan gelen kutsal krallığın merkezidir. Oduduva, aynı

Mircea Eliade, Mitlerin Özellikleri, çev. Sema Rifat (İstanbul: Om Yayınları, 2001), 16.

Olupona, City of 201 Gods, 87.

Molefi Kete Asante, "Ile-Ife", ed. Molefi Kete Asante ve Ama Mazama, Encyclopedia of African Religion (California: SAGE Publications Ltd., 2009), 336 
zamanda kurucu kraldır. Oğulları ve torunlarıysa İle-İfe'de kurulan krallığı sürdürmüşlerdir. Bu soyun bugüne kadar geldiği bilinmektedir. Bu durum, İle-İfe' nin özelliklerini korurken krallığın kendisi de İle-İfe'den beslenmiştir. Yorubaların göçleriyle başka önemli merkezler ve krallıklar oluşsa da İle-İfe her zaman kutsal krallığın merkezi olarak kalmıştır. İle-İfe'den güç alan krallar aynı zamanda orayı özenle korumuşlardır. ${ }^{8}$

İle-İfe, mitolojiden kaynaklanan bu üç temel nedenin yanı sıra insan yaşamına ilişkin özellikleriyle de merkezîliğini korumuştur. İle-İfe; dini, sosyal, siyasal, sanatsal ve kültürel merkezdir. Yorubaların en önemli Orişaları arasında bulunan Oduduva, Obatala (insanı şekillendiren Orişa), Orunmila (İfa: bilgelik ve kehanet Orişası) ve bunlarla ilgili festival ve ritüel uygulamalar önemlidir. Oduduva tapınağının etrafında toplanan başka onlarca Orişaya adanmış tapınaklar da dikkat çekicidir. Sanatsal anlamda özellikle tunç ve demir heykel işlemeciliği kıymetlidir. İnsanlığın ve krallığın beşiği olması ${ }^{9}$ ise inançsal anlamın Yoruba tarihi ve yaşamıyla desteklenmesi anlamina gelmektedir.

İle-İfe'yi merkez yapan bu özellikler temelde iki ana etkene bağlıdır.

232 Bunlar mitoloji ve Yoruba yaşamıdır. Mitoloji geçmişte yaşanmış olanlardır. Yaşam ise mitin yenilenmesi ve yinelenmesidir. Bu nedenle mitoloji, yaşamı biçimlendirirken yaşam, mitolojinin uyarlaması haline gelir. Bu ikisi birbirine paralel özellikler taşırlar. Mitolojide Orişalar ilk faaliyetlerini İle-İfe'de gerçekleştirerek burayı merkez tutmuşlardır. Yorubalar ise hayatlarına uyarladıkları mitolojiyi İle-İfe merkezli olarak yinelemişler ve yaşamışlardır. Çalışmada bu iki hususa dikkat edilerek konu, "Mitolojiye Göre İle-İfe" ve "Yoruba Yaşam Alanında İle-İfe" başlıkları altında ele alınmıştır.

\section{Mitolojiye Göre İle-İfe}

İle-İfe yaşam alanı; Orişa adı verilen tanrısal varlıklar, bunlar adına kurulmuş tapınaklar, festivaller, sunaklar ve ritüellerle doludur. İle-İfe'de Orişaların, Orişa-Kralların ve dişil Orişaların olmak üzere çeşitli tanrısal varlığın tapınakları ve sunak yerleri vardır. Özellikle Ogun (demir ve savaş Orişası), Obatala ve Orunmila (İfa) gibi Orişalar bazı soylar ve klan grupları tarafından takip edilmektedir. Orişalar İkole Orun (Cennet, Cennet Evi)'dan İkole Aye (Yeryüzü veya Yerin Evi)'ye doğru yolculuk yapmışlardır. Aye,

\footnotetext{
8 Mia Sogoba, "Ile-Ife: The Sacred Yoruba City", Cultures of West Africa, 14 Ocak 2019, https://www.culturesofwestafrica.com/ile-ife-sacred-yoruba-city/.

9 Olupona, City of 201 Gods, 90.
} 
yani dünya veya evren, hem kozmosun orta tabakasının fiziksel alanı hem de orada yaşayan insan anlamına gelir. Dünyanın yani Aye'nin merkezinde ise kutsal yerlerle dolu İle-İfe bulunur. ${ }^{10}$

İle-İfe, Yorubalara göre ilk yaratılan yerdir ve Nijerya ülkesinin güneybatı kesiminde yer alan antik bir şehirdir. Son zamanlarda, bu şehrin tarihini MÖ 500 yılına kadar geri götüren kanıtlar keşfedilmiştir. Bu dönemde, İle-İfe çevresindeki Yoruba halkı tarımla geçinirdi ve tükettikleri birçok ürünü evcilleştirmişlerdi. İle-İfe kentinin, Oduduva ve Obatala tarafından dünyanın yaratılmaya başladığı yer olmasından kaynaklı oluştuğu söylenir. Yoruba köken mitine göre, bu tanrısal varlıklar Yüce Tanrı Olodumare tarafından yönetilirdi. İle-İfe, Olodumare'nin emriyle Orişaların yaratılışı başlattıkları ve kurdukları yer olduğu için genellikle Tanrı'nın dünyayı meydana getirdiği şehir olarak kabul edilmiştir. Burası aynı zamanda tüm Yorubaların güçlü ruhsal merkezi olan kutsal mekândır. Çünkü hem mitolojide hem de halk inanışında dünyanın yaratılışı buradan başlamıştır. Obatala burada ilk insanı kilden biçimlendirirken Oduduva Yoruba'nın ilk tanrısal kralı olarak seçilmiştir. İle-İfe Oonisi (kralı), Orişa Oduduva'dan doğrudan inişe geçtiğini iddia etmiş ve ilk Yoruba kralları arasında yer almıştır. Bu nedenle, İle-İfe'nin önemi orijiniyle ve Orişaların bu şehri yaratılış merkezi seçmesiyle doğrudan ilgilidir. ${ }^{11}$

Yorubalara ait farklı yaratılış mitlerinde bazı ortak figürler vardır. ${ }^{12}$ Bunlardan birisi göksel âlemden yer âlemine geçişi ifade eden evrenin ve insanın yaratıldığı mekândır. Burası tanrısal âlemin insan âlemine yansıdığı İle-İfe'dir. Bunun anlamı İle-İfe yeryüzünün ilk yaratılan yeridir, insanın yaratıldığı yerdir ve insan yaşamının başladığı yerdir. Bu nedenle de Yoruba yaşamının başladığı yerdir ve buradan hareketle oluşan medeniyetin de beşiğidir. ${ }^{13}$

Yaratılış süreci Yüce Varlığın güçlü, üretken ve manevi gücünü, kutsal güçle aşıladığı özel yerlerde, bitkiler, nehirler, dağlar ve vadilerde açı̆̆a çıkarmıştır. Yaratılışta etkin olan onaltı primordiyal Orişa dünyaya indiğinde, kendi özel mekânlarını oluşturmuşlardır. Bu özel mekânlar Yorubalar için de

Olupona, 86-87.

1 Molefi Kete Asante, "Ile-Ife", ed. Molefi Kete Asante ve Ama Mazama, Encyclopedia of African Religion, (California: SAGE Publications Ltd., 2009), 336.

12 Canan Seyfeli ve Elif Kul, "Geleneksel Yoruba Dininde Yaratılış ve Ölüm Sonrası Hayat”, Sosyal Bilimler Araştırma Dergisi 16, sy. 32 (2018): 248.

13 Yemi D. Ogunyemi, Introduction to Yoruba Philosophy, Religion and Literature (New York: Athelia Henrietta Press, 1998), 73. 
genellikle mucizevi olayların yaşandığı yerlerdir. Bunlardan birisi İle-İfe'dir. İle-İfe, Obatala'nın ilk insan bedenlerini kilden yontarak biçimlendirdiği ve Olodumare' nin onlara nasıl hayat verdiğini keşfetmekte başarısız olduğu, Orişaların fakir kör yaratıkların etraflarında olup biteni görebilmeleri için bir yol bahşetmesi adına Oludumare'ye yalvardıkları yerdir. Olodumare güneşi ve ayı yarattığında İle-İfe güneş 1şığının ilk dokunduğu "gündoğum yeri"dir. ${ }^{14}$

İle-İfe' nin Yorubalar arasındaki yeri ve konumu, mitolojide yaratılışla ve birçok Orişayla, özellikle Obatala, Orunmila ve Oduduva' yla ilişkilidir. Bu tanrısal âlemden yaşam âlemine geçişte İle-İfe' nin tam anlamıla bir merkez kabul edilmesiyle ilgilidir. İle-İfe'ye atfedilen özellikler mitolojiden kaynaklanırken mitin yaşama yansımasının da en açık örneğini ortaya koymaktadir.

Yoruba sözlü geleneğine ait anlatılara göre Orunmila'nın (İrunMole) da aralarında olduğu önde gelen Orişalar (on altı veya on yedi) İle-İfe' yi, yani evreni (dünyayı, yeryüzünü) insan yaşamı için hazırlayan görevliler arasındadır. ${ }^{15}$ Yoruba anlatıları da İle-İfe'nin ilk yaratılan yer, Cennet Evi ve en kutsal şehir kabul edildiğini ortaya koymaktadır. ${ }^{16}$ Yaratılışın başladığı noktaysa İfa-Vara'dır, saraydır, ana tapınaktır. Yaratılış mitinde Orunmila elini deniz kabuklarına daldırmış ve bir ağ çıkartarak su üstüne fırlatımıştır. Tekrar elini daldırmış ve çıkardığı toprağı ağın üstüne atmıştır. Üçüncüsündeyse beş parmaklı bir horoz çıkarmış ve toprağı ağın ve suyun üstüne yayması için onu ağın üzerine sürmüştür. Horoz toprağı deşme ve saçma hareketleriyle yaymaya başlamıştır. Orunmila işin yavaşladığını görünce kendisi inmiş ve küçük yerin büyütülmesi için; "Hızlıca genişle, hızlıca genişle, hızlıca genişle!" emrini vermiştir. Sonra yeryüzü genişlemiştir. ${ }^{17}$ Başka bir mitte horozu yönlendiren Oduduva'dır. Buna göre Olodumare'nin oğullarından birisi olan Oduduva, ölen erkek kardeşinin eşyalarını çalmış ve zincirle gökten sulu dünyaya doğru inmeye başlamıştır. Deniz kabuğundaki kumu, suların üzerine dökmüş ve tavuğu üstüne atmıştır. Güçlü ve efsanevi tavuk, büyük pençeleriyle kumları tekmelemiş, kazmış, ezmiş ve sonra suyun üzerinde kuru toprak oluşturmak için

\footnotetext{
Sogoba, "Ile-Ife".

15 Diedre L. Badejo, "Orunmila", ed. Molefi Kete Asante ve Ama Mazama, Encyclopedia of African Religion (California: SAGE Publications Ltd., 2009), 507.

16 Molefi Kete Asante, "Orisha-Nla", ed. Molefi Kete Asante ve Ama Mazama, Encyclopedia of African Religion (California: SAGE Publications Ltd., 2009), 507.

17 Philip John Neimark, The Way of The Orisa: Empowering Your Life Through The Ancient African Religion of Ifa, (San Francisco: Harper Collins Publishers, 1993), 58.
} 
saçmıştır. Tavuğun pençelerinin derinleştiği yerler vadilere, pençeleri arasındaki el değmemiş yerler de tepelere ve dağlara dönüşmüştür. Oduduva'nın kumu döktüğü noktaya, yeryüzünün oluşmaya başladığı yere İle-İfe adı verilmiştir. Ayrıca o noktaya bütün bitki yaşamının kaynağı olan ve Hayat Ağacı haline gelen ilk palmiye çekirdeği dikilmiştir. ${ }^{18}$

Hayat Ağacı imgesi merkez simgeciliğinde önemli bir yere sahiptir. Eliade, kozmik ağaç derken bu ağacın Gök, Yer ve Cehennemi bir tutan eksen olduğunu söylemiştir. ${ }^{19}$ Ancak Cehennem ya da kötü ceza yeri fikri, Geleneksel Yorubalarda yoktur. Çünkü her şey tanrısal ve iyidir. Tanrısal âlemde, kötü ölümle ölenler için geçici kalınan bir yer vardır. Bu, reenkarnasyonla Cennet'e gidinceye kadar işleyen bir mekândır. Geçici kalınan bu yer her ne kadar Cehennem anlamı taşımıyorsa da Cennet'ten uzak kalınan bir yerdir. Bu nedenle bu mekâna iyinin kötüsü denebilir. Ama Yorubalarda ne fikir ne de ifade olarak 'yeraltı' nın bulunmayışı Cehennem fikrinin olmamasıyla ilişkilidir. ${ }^{20} \mathrm{Bu}$ nedenle Yorubalarda Hayat Ağacı figürü Yer ile Gök'ün eksenidir, ağacın kökünün toprağın altında olması da Cehennem fikrini doğurmaz. Eksen ise yerin göğe, göğün yere açıldığını simgeler. $\mathrm{Bu}$, bir mitte yer alan altın zincire işaret etmektedir.

İle-İfe dünyanın ve yaratılışın merkezi olduğu gibi bu merkezden etrafa, hale gibi yayılan bir kutsallığı da ifade eder. Bu, dünyanın yaratılışına paralel bir durumdur. Yeryüzünün yaratılış noktası Orunmila mitinde açık ifadesini bulmuştur. Buna göre Orunmila'nın toprağı attığı ve genişlemesini emrettiği yer bugünkü İle-İfe'deki İfa-Vara'dır. İle-İfe Obatala mitinde de başlangıç yeridir. Obatala burada insanı şekillendirmiştir. Ayrıca burası Oduduva'nın bir kral Orişaya dönüşerek Yoruba krallığını kurduğu yerdir. ${ }^{21}$ Dolayısıyla mitte olduğu gibi insanlık Yorubalardır, evren ise Yorubaların merkezidir, yani İle-İfe'dir. İle-İfe yaratılışın başladığı yer olması nedeniyle Orunmila' nın evi diye tanımlanmıştır. Yorubaların manevi ve politik merkezi olmuştur. ${ }^{22}$ İle-İfe yeryüzünün, hayatın ve insan için gerekli her şeyin ilk biçimlendiği yerdir. Yoruba yaşamının başladığı ve etrafa yayıldığı noktadır. İle-İfe, bu sebeple de Yorubalar için tarihsel, siyasal, toplumsal ve dinî merkez olmuştur. Burası Orişalar arasında en fazla bilgi ve hikmet Orişası Orunmila

\footnotetext{
Sogoba, "Ile-Ife".

Mircea Eliade, İmgeler Simgeler, çev. Mehmet Ali Kılıçbay (Ankara: Gece Kitapları, 1992), 22-23.

Seyfeli ve Kul, "Geleneksel Yoruba Dininde Yaratılış ve Ölüm Sonrası Hayat", 263-64.

Asante, "Ile-Ife", 336.

22 Badejo, "Orunmila", 508.
} 
ile ilişkilendirilirken onun evi, yurdu ve vatanı olarak kabul edilmiştir. ${ }^{23}$ Böylece Yorubalar için yaratılıştan itibaren İle-İfe ve doğrudan burasıyla ilişkili olan varlıklara kutsallık atfedilmiştir. Tanrısal âlemin varlıklarının oluşturduğu bu insan âlemi, bir bakıma onların devamı niteliğindedir. Bundan dolayı Yorubalar kendilerini gündelik yaşamlarında ritüel uygulamaları icrada yöneldikleri kişisel Orişasının çocukları olarak görmektedirler. ${ }^{24}$ Yaratılış itibariyle evrene, dünyaya, dünya hayatına ve insana kutsallık atfetme ve onları iyi kabul etme söz konusudur. Aslında bunun nedeni yaratılış mekânının tanrısal âlem olması, dünyanın temelinin kutsal ve bu temelde yükselen evrenin de kutsal olmasıyla alakalıdır. Bu nedenle tanrısal olan yaratılmış âlemin en kutsal yeri İle-İfe'dir.

İle-İfe' yle ilişkili olarak farklı yaratılış mitlerinde ya da tek bir mitte farklı özellikleriyle birlikte yer alan Orunmila, Obatala ve Oduduva üç önemli Orişadır. Yaratılışın başladı̆̆ı tanrısal âlemde Yüce Tanrı Olodumare, Orişalara görev verdiğinde hedef evrenin ve insanın yaratılışıdır. Bunun için yeryüzünü kaplayan primordiyal suyu temizleme görevi Obatala ve Orunmila'ya verilmiştir. Bahsi geçen horoz figürlü yaratılış mitlerinde evrenin ve insanın yaratılışı İle-İfe' den, İle-İfe' deyse İfa-Vara' dan başlamıştır. Obatala, İle-İfe ile özdeşleşmiş bir Orişadır. Fakat onun Oduduva tarafından yaratılıştaki hatalarından dolayı sürülmesi ve işinin tamamlanması söz konusudur. ${ }^{25}$ Başlangıç yeri İle-İfe olan başka bir mitte Obatala altın zincirle göksel âlemden yeryüzündeki suya inmiş ve suya akseden görünüşüne benzer şekilde çamurdan insanlar biçimlendirmiştir. Sonra susamış ve palmiye şarabı içerek sarhoş olmuştur. Sarhoş halde işine devam edince uzuvlarında eksiklik bulunan kusurlu insan bedenleri şekillendirmiştir. Ayrıca yaptıklarının güzel olduğunu da farz etmiştir. ${ }^{26}$ Mitin başka bir versiyonunda Obatala yine sarhoş olmuştur. Olodumare' nin verdiği yaratılış objeleri olan kum ve salyangoz kabuğunu kara oluşmayacak şekilde yanlış kullanmıştır. Bu hata, kara insanı değil de deniz insanı, yani balık insan oluşturmaya yol açacağından Oduduva ona mâni olmuştur. Sonra Oduduva diğer Orişaların ona sadakatiyle yeryüzünü oluşturmuştur ve böylece insan

23 Asante, "Ile-Ife", 336.

24 J. D.Y. Peel, Religious Encounter and The Making of The Yoruba, (Bloomington \& Indianapolis: Indiana University Press, 2003), 102.

25 Ibram H. Rogers, "Obatala”, ed. Molefi Kete Asante ve Ama Mazama, Encyclopedia of African Religion, (California: SAGE Publications Ltd., 2009), 470.

26 David A. Anderson/Sankofa, "The Golden Chain", Creation Stories from around the World Encapsulations of some traditional stories explaining the origin of the Earth, its life, and its peoples, ed. Bruce Railsback, Word Edition, (Georgia: University of Georgia, 2000), 23-24. 
yaşamı başlamıştır. ${ }^{27}$ Bir Orişanın eksikliğini gösteren bu mit olumsuz gibi görünse de Yoruba yaşamını Obatala'nın zıt yönlü özelliğiyle şekillendirmiştir. Yani kutsallıkta bir eksiklik yoktur. İle-İfe'de ve başka yerlerde Obatala'ya sitayiş gösterilirken değer verilir, diğer taraftan ona adanmış festivaller ve ritüellerde o, öfkeli tasvir edilir. Bu değerini küçültme anlamı taşımadığı gibi insanı eksik uzuvlarla şekillendiren Obatala engellilerin Orişası kabul edilmiştir. Engellilere eni Orişa (Obatala'nın insanları) denmiştir. ${ }^{28}$

Oduduva, Obatala'yla sözlü gelenekte veya litürjik uygulamalarda da yan yana gelirken benzer bir rolü üstlenmenin ötesinde birbirini tamamlayıcı niteliktedir. Oduduva'nın dişil yönüne dikkat çeken Yoruba bilimci E. Bolaji Idowu, İfa kehanet sisteminin kutsal şehri İle-İfe'de halen uygulanan litürjinin sözlerinde mevcut olan dişil Orişa geleneğinin Ado' da ve Güneybatı Yoruba yaşam alanında uygulandığını söylemiştir. ${ }^{29}$ Bununla ilişkilendirilen Oduduva bir sözlü anlatıda Obatala'nın karısı olarak nitelenir. Buna göre Obatala Cennet'i, Oduduva ise yeryüzünü, ikisi ise yer ile göğün birliğini, birleşmesini sembolize eder. Aslında bu, mite de uygundur. Çünkü zincirle gökten inen Obatala'nın işini yerde Oduduva tamamlamıştır. Bu sözlü gelenek Oduduva'yı ana, Obatala'yı ise baba ve eril Orişa kabul etmektedir. Bu ikisi suyu temsil eden Yemonja (Obatala) ve toprağı temsil eden Aganju'da (Oduduva) bir araya gelirken Oduduva bir aşk Orişası ve ana Orişa kabul edilmiştir. ${ }^{30} \mathrm{Bu}$ Orişalar gök ile yerin, göksel âlemle yer âleminin, tanrısal âlemle insan âleminin ekseni olan İle-İfe ile ilişkilidir.

Olodumare, mitolojide Oduduva'yı varlığın özü, gerçeği doğuran hikâye ve uyanmadan önceki rüya şeklinde tanımlar. Ona yaratılışta Orişaların çalışmalarını denetleme görevi verir. ${ }^{31}$ Oduduva bu görevini, İleİfe'de Obatala'nın sarhoşken yaratma eylemine müdahale ederek uygular. ${ }^{32}$ Evrenin oluşumu ve insan yaşamının İle-İfe'de başlamasıyla Olodumare tüm idari ve siyasi görevleri İle-İfe' nin ilk kralına (oba), Oduduva'ya teslim eder. ${ }^{33}$ İle-İfe'de kral Oduduva'nın eşleri, Olokun ve Oşaara hangilerinin değerli

\footnotetext{
Bibeli Bible of Yoruba People Children of The Good Morning, (The University of African Art Press Electronic Book Media, 2007), 29-30.

8 Rogers, "Obatala", 471.

E. Bolaji Idowu, Olodumare: God In Yoruba Belief, (London: Longmans, 1962), 24-25.

30 Maulana Karenga, "Oduduwa”, ed. Molefi Kete Asante ve Ama Mazama, Encyclopedia of African Religion, (California: SAGE Publications Ltd., 2009), 474-75.

1 Bibeli, 26.

32 Bibeli, 28-30.

33 Bibeli, 36.
} 
olduğu konusunda kavga ederler. Oduduva ikisinin aynı derecede olduğuna karar verir ve sorunu çözümler. Böylece İle-İfe'deki yaratılışın merkezi, tahtının ardındaki İgba İva'nın (varlığın sukabağı) yıkılmasını engellemiş olur. $^{34}$

Nil Vadisi araştırmaları uzmanı diye tanıtılan ve isim belirtilmeyen bir araştırmacı, Oba Ecun'un (Cecilio Perez) iki çalışmasını değerlendirdiği blog sayfasındaki tanıtım yazısında İle-İfe ve Yoruba yaşamında en etkili mitlerden birisine yer verir. Bu mite göre Oduduva erildir, ilk insan ve ilk kraldır. Olodumare yeryüzünde ilk insanı yaratır ve o da krallığını kurar. Tüm Orişaların babası, yeryüzüdür. Ama öncesinde bir gaz ve karartıdır. Yeryüzü bunlardan oluşturulur. Yeryüzünün en büyük dağından Yembo (Olokun), yani Oduduva'nın karısı yaratılır. Olokun'un yaratılışı yeryüzündeki suların; okyanuslar, denizler, nehirler ve göllerin oluşumunu ifade eder. Onunla aşk, evlilik ve yaratılış gelir. Beşeri kimliği, kralın karısı, krallığın en güzel kadınıdır. Geceleri güzellik timsali Ay'a (Nana Buruku) dönüşür. Yorubalarda Orişalar arasında Oduduva ve Yembo baba ve ana Orişalardır. Onları kimse ayıramaz, aşkları durduğu vakit ahir zamanın son savaşı olacaktır. ${ }^{35}$ Dünyanın yaratılışta merkezi olması gibi dünya hayatının sonunda da İle-İfe merkezlik özelliğini sürdürmektedir.

İle-İfe' nin Oduduva'yla ilişkisinde hem yaratılış merkezi hem de insan yaşamının ve krallığın başladığı yer olması önemlidir. Bunlarla ilgili mitolojide oynadığı rolden dolayı İle-İfe, hayat bahçesi anlamına gelmektedir. ${ }^{36}$ Oduduva ve Obatala'nın savaşını konu alan bir köken mitinde Oduduva, yeryüzünü oluştururken İle-İfe'de saldırıda bulunur, Cennet'in/Göğün altında yaratılıştaki suyun içine kumu akıtır, sonra yeri (İle Aye) sertleştirerek ona şekil verir. Obatala ise Oduduva'nın kibirli emrini ve ona meydan okumasını hoş karşılamaz. Bu, sarhoş olan Obatala'nın işini Oduduva'nın tamamlamasıyla oluşan kindir ve aralarında bir savaşın başlamasına yol açar. Bu mitik imge, mitolojinin Yoruba yaşam alanına yansıdığı yerde halen Obatala festivalinde canlandırılan bir oyuna dönüşmüştür. ${ }^{37}$

\footnotetext{
4 Bibeli, 41-44.

35 "Creation Stories from Around the World Afro-Carribean Yoruba, unknown origins-1989 CE Mythology of the Yoruba Religion A recounting and explanation of Yoruba creation stories by Oba Ecun, the Yoruba name of Cuban-born Cecilio Perez, Yoruba practitioner and scholar. Text and notes taken from Ita: Mythology of the Yoruba Religion, by Oba Ecun, Obaecun Books, Miami 1989.", Dhwtys Learning Center, PDF Edition, 2018, 2.

36 Ogunyemi, Introduction to Yoruba Philosophy, Religion and Literature, 73.

37 Karenga, "Oduduwa”, 475.
} 
Yeryüzünün ilk mekânı, merkezi olan İle-İfe'nin Cennet'in yansıması olması söz konusudur. Yorubalar arasında İle-İfe en kutsal şehir ve Cennet Evi olarak kabul edilir. ${ }^{38} \mathrm{Bu}$, bahçe ve ağaç gibi bitkilerle de alakalıdır. Mite göre başlangıçta göksel âlemde/Cennet'te ve yeryüzünde su ile ilişkili ağaç gibi şeyler henüz yoktur. Olodumare ve Orişalar Cennet'te ağaç yetiştirmek istediklerinde Olodumare, önce yağmur Orişası Eji'ye Cennet'in her yerine yağmur yağdırması için izin verir. Toprak ıslanıp nemlendikten sonra Olodumare ormanlar Orişası Iju'ya ağaç yetiştirmesi için emir verir. İju: "Topraktan her çeşit ağaç ve bitki yetişsin." diye emreder. Boş araziden ağaçlar tek tek çıkmaya başlar. Tatlı ve acı, yumuşak ve dikenli, zehirli ve şifalı çeşitli ağaçlar, bitkiler filizlenerek büyürler. Bir kısmı meyveli iken bir kısmı çiçeklidir. Çoğunluğu büyük köklüyken birazı da köksüzdür. Olodumare ağaçları denetler ve böyle olsun diye onaylar. ${ }^{39}$

Mitolojide tasvir edilen Cennet'in yeryüzüyle aynı olduğu anlaşılmaktadır. Yorubalar için dünyanın ve dünya hayatının kötü olmaması, hatta kötü yer, cehennem olmamasının nedeni de budur. Yeryüzü inşasından önce göksel âlemde böyle bir yaratma işleminin gerçekleştirilmesi prototip bir yaratılışa işaret etmektedir. Dolayısıyla yeryüzü de buna göre şekillendirilmiştir. Yoruba kozmosunda yer ile göğün ekseni İle-İfe'dir. İkisinin bir bütün olduğu ve bu bütünlüğün giriş ve çıkış ya da birbirine açılan kapı özelliğinin İle-İfe'de bulunduğunu göstermektedir. Gök ile yerin bütünlüğünü, iç içe geçmişliğini bazı hususlarda açıkça görmek mümkündür. Örneğin, kökeni göksel âlem olan Orişaların İle-İfe' yi oluşturması ve artık İleİfe'de kalması söz konusudur. Bu, İle-İfe'nin gökyüzüne açılan kapı ve yeryüzünün merkezi, Cennet olduğunu göstermektedir. Hayat Ağacı'nın burada dikilmesi ${ }^{40}$ de bunu göstermektedir. Göklerdeki gibi İle-İfe'de de kutsal bir krallığın kurulması bu toprakların kutsallaştııılmasında ve yeryüzünden olduğu kadar gökyüzünden de bir parça taşıması anlamında iki mekânın birleştiği yer olur. Böylece İle-İfe, göksel ile yersel olanın iç içe geçtiği ve sonuçta her şeye bir kutsallığın atfedildiği bir merkez olup Yoruba inanç sisteminde hem Orişaların hem de insanoğlunun evidir. Çünkü göğün yere, yerin göğe açılan kapısıdır.

Asante, "Orisha-Nla", 507.

9 Bibeli, 14.

40 Sogoba, "Ile-Ife". 


\section{Yoruba Yaşam Alanında İle-İfe}

Geleneksel Yorubalarda dinin bütün sadeliği ve sıradanlığıyla yaşamın her noktasına bir şekilde dokunduğunu görmek mümkündür. Yoruba aklının ürünü İle-İfe'ye sanatsal, kültürel ve politik olsun veya başka yönlerden olsun mutlaka din orijinli bir değer biçilmesi söz konusudur. Mitolojik arka planından, tarihsel geçmişinden ve festivaller, ayinler ve ritüellerden İleİfe' nin yaşam ile ilgili her noktanın ve bütün yolların kendisinde kesiştiği bir merkez olduğu anlaşılmaktadır.

İle-İfe'nin merkezliğini ortaya koyan kökeni, tarihi, dinî konumu ve daha birçok özelliği sözlü gelenek vasıtasıyla bugüne aktarılmıştır. Zengin bir sözlü kültüre sahip Yorubalar arasında İle-İfe'nin kökenine dair şu söylenmektedir:

“Denizin veya okyanusun kaynağını bilmiyoruz

Lagünün (deniz kulağı) kaynağını bilmiyoruz

Öyleyse, İle-İfe Oodaiye (ilk) tarihinin kaynaklarını veya başlangıçlarını asla bilemeyiz." 41

Bu sözlerde İle-İfe, deniz, okyanus gibi yeryüzündeki doğa

240 varlıklarıyla karşılaştııılır. Onlar dahi bilinmezken İle-İfe'nin bilinmesinin imkansızlı̆̆ı vurgulanır. İle-İfe, göksel âlem gibi ulaşılmaz, dolayısıyla kutsal olarak tanımlanır. Bu İle-İfe' nin tarihiyle de ilgilidir. İle-İfe hakkındaki temel bilgiler mitolojiye dayalıdır. Sözlü gelenek yanında modern dönem arkeolojik çalışmalarda elde edilen veriler de vardır. Bütün bu bilgiler değerlendirildiğinde İle-İfe' nin temel özelliklerini Yoruba yaşam alanındaki etkisiyle birkaç kalemde ortaya koymak mümkündür.

İle-İfe'nin Yoruba yaşamına etkisini ortaya koyan özelliklerinden birincisi yaratılışın beşiği olmasıdır. Burada yaratılıştan kasıt öncelikli olarak Yoruba aklındaki evrenin, dünyanın yaratılmasıdır. Dolayısıyla İle-İfe, hem evrenin yaratılışının hem insanın yaratılışının/oluşumunun ve hem de kutsal kan ve krallığın beşiğidir. İle-İfe bu özellikleriyle dinlerde mevcut olan dini merkez figürünü tam anlamiyla ifade etmektedir. Yoruba bilimci Idowu, İleİfe'nin bu çoklu özelliğini şöyle tanımlamaktadır:

"İle-İfe: aşağıda (yeryüzünde) yaratılanların ilki; her şeyin orijinal evi; günün doğduğu yer; büyülü, kutsal şehir; tanrısal varlıkların ve gizemli ruhların evi! Bunlar, İle-İfe'ye ilişkin çocukluk bilgimizin bir bölümünü oluşturan çok çeşitli fotoğraflarıdır. Bugün bile, birkaç yıllık Batı sofistikesine

41 Obayemi, “Ancient Ile-Ife”, 151. 
rağmen, şehir hâlâ Yoruba halkı için belli bir büyüye sahiptir, çünkü onların ulusal damarları boyunca akan dinî kanın yayıldığı kalptir." 42

İle-İfe'nin Yoruba yaşam alanında etkisi bulunan ikinci özelliği Orişaların evi olmasıdır. Yaratılışın gerçekleşmesinde rol oynayan Orişalar, göksel âlemden inip yaratılışı İle-İfe'de başlatmışlardır. Bu yüzden İle-İfe'ye ilk ayak basan varlıklar onlardır. Yoruba yaşamında dikkat çeken Orişaların en önemlileri İle-İfe ile özdeşleşmiştir. İle-İfe'deki bazı yerler bu tanrısal varlıklarla ilişkilendirilerek adlandırılmıştır. Cadde ve sokaklara kasırga Orişası Oya, Tanrı-kral ve modern yönetici hanedanının kurucusu Oduduva gibi Orişaların isimleri verilmiştir. ${ }^{43}$

İle-İfe'nin Yoruba yaşamını etkileyen temel özelliklerinden üçüncüsü insanlığın beşiği olmasıdır. Mitolojiye dayalı bu özellik Yoruba halkının beşiği olarak ifade edilse de insanın yaratılış fikriyle ilişkilidir. Sözlü gelenekte ve mitolojide farklı anlatımlar ve versiyonlar vardır. Bunlardan birinde Olorun'un gökten yere sarkıttı̆̆ı zincirle Oduduva (tüm erkeklerin atas1); bir horoz, bir miktar toprak ve bir palmiye çekirdeğiyle yere iner. Oduduva, toprağı suya fırlatır ve horoz toprağı deşerek saçarken palmiye çekirdeği on altı krallığı temsil eden on altı ağaca dönüşür, böylece kara oluşur. Bu mitin farklı versiyonları da vardır. Ayrıca her Yoruba kasabası, soyu ve Orişasının kendine has bir miti olmakla beraber hepsinde İle-İfe, bugünkü Yoruba yerleşim yerlerinin kendisinden dağıldığı ana merkezdir. ${ }^{44}$

İle-İfe'nin Yoruba yaşam alanını etkileyen özelliklerinden dördüncüsü kutsal kanın, krallığın kurulduğu merkez olmasıdır. Oduduva yaratılış mitinde; yeryüzü insanlar için yaşanabilir kılındıktan sonra Oduduva, krallığ1 kurarak İle-İfe krallı̆̆ının ilk obası, yani kralı olmuştur. ${ }^{45}$ İle-İfe kutsal şehri hem mitolojide hem de gerçekte yaşamın merkezinde olmuştur. Bu, İle-İfe'ye Yorubaların en kutsal şehri olma özelliğini kazandırmıştır. Bu en kutsal şehrin en kutsal yeriyse yaratılışın ve insanlığın başlangıç noktası ve Hayat A ğacının dikildiği İfa-Vara'dır. ${ }^{46}$ İfa-Vara İle-İfe'nin kalbi, krallık sarayının durduğu yerdir. İle-İfe'nin, Oduduva'nın okyanusları ve yeri yarattığı, ilk krallığı kurduğu, evlatlarının on altı Yoruba krallığını kurduğu yer olduğuna

\footnotetext{
Idowu, Olodumare, 11.

Olupona, City of 201 Gods, 90.

44 BioDun J. Ogundayo, "Yoruba", ed. Molefe Kete Asente ve Ama Mazama, Encyclopedia of African Religion, (California: SAGE Publications Ltd., 2009), 739.

45 Andrew Apter, "The Historiography of Yoruba Myth and Ritual", History in Africa 14 (1987): 3.

46 Rogers, "Obatala", 471.
} 
inanılmaktadır. İle-İfe, hala en çok saygı gören Yoruba krallarının evidir ve festivallerin çoğunluğu burada yapılmaktadır. ${ }^{47}$ Bazı söylencelere göre Oduduva henüz hayattayken veya ölümünden kısa süre sonra, oğulları ve torunları İle-İfe'den dağılarak kendi krallıklarını kurmuşlardır. Bu krallıkların sayısı versiyonlarda farklıdır, altı olduğu da söylenmektedir. ${ }^{48}$ Kendi krallıklarını kurmak için şehirden ayrılan on altı kraliyet çocuğundan bahsedilmektedir. Mitlerden anlaşılan tüm Yoruba şehirlerinin kaynağı İleİfe'dir. Buna göre Oduduva, çocuklarına yeni topraklar ele geçirme ve yönetme hakkını temsil eden kutsal bir taç ve kılıç vermiştir. Bu yeni krallıklar siyasi anlamda İle-İfe'den bağımsız olsalar da manevi, politik, gelenek ve ritüel uygulamalar bakımından oraya bağlıdırlar. ${ }^{49}$ Benin, Oyo, Owu, Keto gibi Yoruba krallıkları kutsal şehre bağl11klarını göstermek durumundadırlar. Kralları öldüğünde yeni kralın kabul görmesi için gerekli olan kutsal tacı ve kılıcı almak üzere İle-İfe'ye bir elçi grubu gönderirler. Karşılığında kutsal İle-İfe' yi korumaya yemin ederler. ${ }^{50}$ Dağılmış krallıkların İle-İfe'ye bağımlılığını gösteren başka bir örnek ise Benin krallığı gibi diğer Yoruba krallarının da kısmen ölümden sonra İle-İfe'ye dönmeleridir. Özellikle Benin'de ölen kralların cesetlerinin bir kısmı mezarlık için İle-İfe'ye gönderilir. İle-İfe' de Orun Oba Ado (Benin krallarının Cenneti) adlı yer tırnak, saç gibi krallardan parçaların yerleştirildiği eski bir mezarlıktır. ${ }^{51}$

Nimi Wariboko'nun kraliyet ailesinin yaşlı bir üyesinden aldığı bilgiye göre İle-İfe Cennet, dünya ve yeraltı dünyasının kavşak noktasıdır. Ayrıca bu kent tanrısal olanla bedensel olanın buluştuğu merkezi noktadır. Kutsal krallı (Ooni) ise hem İle-İfe'nin hem de İle-İfe'nin kutsal merkezinin bedenidir. Kutsal krallık sarayı ise var olan ve var olacak olan her şeyin tam merkezinde durur. Kutsal krallığın insanlarıysa tanrısallığın ve toprağın etli beden olarak merkezi noktada buluştuğu kutsallardır. Aynı zamanda bu şehir üç ana yolun kesişim (oríta) noktasıdır. Krallık, yani kutsal kral ve şehir yöneticisi şehrin kendisidir. Kral, toprağın sahibi olan Ooni-ile'dir. Oduduva'nın halefi olarak kral, ona ait olan ve onu sembolize eden toprağ bedenlendirir. Krallık kutsal şehrin ve kutsal insanlarının mitik hayalini bir yerde, onun kutsal bedenselliğinde yoğunlaştırıyor gibidir. Şehrin tanrısal

Dierk Lange, "Ife and the Origin of the Yoruba: Historigraphical Considerations", Ife: Annals of the Institute of Cultural Studies, 6 (1995): 307.

48 R. C. C. Law, "The Heritage of Oduduwa: Traditional History and Political Propaganda among the Yoruba", The Journal of African History, 14/2 (1973): 210.

49 Sogoba, "Ile-Ife".

50 Sogoba, "Ile-Ife".

51 Law, "The Heritage of Oduduwa", 211. 
otoritesi kutsal aşe (tanrısal güç) tarafından korunur. Krallığın kendisi adına hüküm sürdüğü Oduduva, topraklarla güçlü bağını sürdürür. ${ }^{52}$

Kraliyet sarayı İle-İfe' nin kalbi olan Enuva'dadır. Sarayda kralın eşleri, prensler ve prensesler için de binalar yer almaktadır. İle-İfe'de Oduduva'nın başka tapınakları da vardır. ${ }^{53}$ Geleneğe göre Oduduva'nın en genç, bazı kaynaklarda en yaşlı, oğlu Oranmiyan İle-İfe'de kalır, İle-İfe krallı̆̆ının ilk kralı olmuş ve hem dinî hem de politik idare merkezi olan İle-İfe'yi yönetmiştir. ${ }^{54}$ Opa Oranmiyan İle-İfe'nin babası ve İle-İfe'nin kahraman savaşçısı olarak anılmıştır. ${ }^{55} \mathrm{O}$, ölmeden önce oğlunu düşmanlarının İle-İfe' yi insan düşüncesinde küçültmelerine izin vermemesini öğütlemiştir. Cesaretli ve kahraman gibi davranmasını böylece İle-İfe'nin yaşayabileceğini söylemiştir. İle-İfe'nin tarihsel ününün daha çok Oranmiyan'dan kaynaklandığı söylenebilir. Oranmiyan, İle-İfe halkı ve toprakları için birçok kahramanlık göstermiş ve Oduduva'nın oğlu olarak İle-İfe' ye yakışır bir kral olmuştur. Oranmiyan öldükten sonra bile İle-İfe topraklarının saldırıya uğramaması onunla ilişkilendirilmiştir. İsanlar İle-İfe'nin ihtişamını sürdürmesinden hareketle onun hala yaşadı̆̆ını söylemişlerdir. ${ }^{56}$

İle-İfe, 201 veya 401 Orişayla anılmasına paralel olarak tapınakları ve kahinleri de çok olan bir şehirdir. Kahin veya rahip denebilecek bu din adamlarının hem dinî ve hem de sosyo-politik fonksiyonları vardır. Dini ritüellerin idarecisi babalavolar İle-İfe'de en çok görünen erkek rahiplerdir. ${ }^{57}$ Aslında bu iki yönlü özellik, Yoruba dininde gök ile yer, krallık ve dinî merkez İle-İfe, din adamlarındaysa dinî ve siyasi özellikler bir arada bulunur.

Din adamlarında olduğu gibi İle-İfe önemli festivallerin ve ritüellerin de merkezidir. Bunlar arasında en dikkat çekeni Olodumare' ye ibadet anlamı taşıyan ritüeldir. Çünkü Yorubalarda Olodumare' ye tapınım daha çok soyut şekildedir. Bunlar mitoloji, sözlü gelenek, halk söylenceleri, ata sözleri, deyimler ve anlık dualarda açı̆̆a çıkmıştır. ${ }^{58}$ Ancak Yoruba bilimci Idowu, Olodumare'ye doğrudan ibadet şeklinin zamanla silikleştiğini söylemiştir.

52 Nimi Wariboko, "The King's Five Bodies:: Pentecostals in the Sacred City and the Logic of Interreligious Dialogue", Journal of Africana Religions, 2/ 4 (2014): 484-85.

53 Emmanuel Olufemi Omisore, Ime Johnson Ikpo ve Godwin Ehis Oseghale, "Maintenance Survey of Cultural Properties in Ile-Ife, Nigeria", Journal of Building Appraisal, 4/4 (Mart 2009): 258.

54 David D. Laitin, Hegemony and Culture: Politics and Change Among the Yoruba, (Chicago: University of Chicago Press, 1986), 111.

55 Harold Courlander, Tales of Yoruba Gods and Heroes, (New York, Crown Publishers, 1973), 195.

56 Courlander, 56.

57 Olupona, City of 201 Gods, 98.

58 Canan Seyfeli ve Elif Kul, “Olodumare/Olorun: Geleneksel Yoruba Dininde Yüce Tanrı”, Sosyal Bilimler Araştırma Dergisi 17, sy. 33 (2019): 29-36. 
Bunun kanıtı olarak da hala devam eden İle-İfe'yle ilgili bir uygulamayı göstermiştir. Buna göre İle-İfe kraliyet sarayının bir rahibi önce beyaz tebeşir ile bir daire çizer. Ardından bu dairenin tam merkezine, toprağa soğuk suyu sel gibi boşaltır. Sonra kola fıstığı sunumuyla dua eder. Bu ritüel, kraliyet rahibi tarafından günlük olarak tekrarlanırken bireyler bunu ancak ilhami bir yönlendirme ile uygulayabilmektedirler. ${ }^{59} \mathrm{Bu}$ ritüel uygulamada, İle-İfe'nin Olodumare'ye tek ulaşım yeri, yeryüzünün göksel âleme, Olodumare'ye açılan tek kapısı, dolayısıyla O'na tek somut ulaşım mekânı olduğuna işaret etmektedir.

İle-İfe'de ritüel merkezi Cennet, dünya ve yeraltı dünyası arasındaki kesişim merkezidir. Bu nedenle cenaze törenlerinde Yorubalar, ölen kişinin ruhunun İle-İfe' ye giden en düz yolu kullanması ve yolda oyalanmaması için dua ederler. Geçmişte, sevilen birini kaybedenler ölümün nedenini kutsamak ve kötü ölüm olup olmadığını anlamak için İle-İfe'ye yolculuk yaparlardı veya ölen kişi bitmemiş bir iş varsa onu akrabalarının bu yolla duymalarını umardi. ${ }^{60} \mathrm{Bu}$ ifadeler İle-İfe'nin göksel âleme ulaşma merkezi olduğunu göstermektedir.

Oduduva'nın yeryüzünün tanrısal oluşumunu denetlemesi için Olodumare tarafından görevlendirilmesi O'nun ritüel yaşamda da etkili bir Orişa olmasını, özellikle İle-İfe' de uygulamalarda da önemli bir yer tutmasını sağlamıştır. Bu durum onun atasal Orişa olmasıyla da ilgilidir. O, özellikle İleİfe' de Orişa olarak tutulur. İle-İfe Oduduva tapınağ ${ }_{1}$ Ogun, Oke İtaşe/İfa'nın evi, Obameri ve Obagede, Oluorogbo ve Obatala gibi Orişalara adanmış bütün tapınakların merkezindedir. Tarihsel ve arkeolojik araştırmalar da şehirde onun Obatala'yla birlikte üst düzeyde öneme sahip olduğunu göstermektedir. ${ }^{61}$ Kurucu kral ve atasal Orişa olan Oduduva'dır. Kutsal metin Odu İfa'da insan varlığı onunla ilişkilendirilerek omo Oduduva, (Oduduva'nın çocukları) diye tanımlanır. Yorubalar da insanlığın ondan türediğine inanırlar, dolayısıyla kendilerini insanoğlu (eniyan) ve dünyaya iyiliği getirmek için seçilmiş olanlar diye tanımlarlar. ${ }^{62}$

İle-İfe, Oduduva adına yapılan türbe tapınakların, kurban sunuları ve festivallerin de merkezidir. Bu uygulamalar Yorubalar için Oduduva'nın

\footnotetext{
59 Idowu, Olodumare, 142; Ayrıca bkz. Ushe Mike Ushe, "God, Divinities and Ancestors in African Traditional Religious Thought", Igwebuike: An African Journal of Arts and Humanities, 3/4 (2017): 165.

60 Sogoba, "Ile-Ife".

61 J. 'Sina Ojuade, “The Issue of 'Oduduwa' in Yoruba Genesis: the Myths and Realities", Transafrican Journal of History, 21 (1992): 139, 146, 152.

62 Karenga, "Oduduwa”, 475.
} 
mitolojideki yerine göre şekillenmiştir. İle-İfe; yaratılışın, dünyanın, insanlığın ve krallığın merkezi olarak göksel âlemden inen tanrısal varlık ve ata figürü olan Oduduva'yla ilişkilidir. Bu merkezden başlayan Yoruba dininin yayılışı zamanla Oduduva merkezde olmak üzere Obatala'ya, Ori'ye Ogun'a, Eşu'ya ve Egungun'a saygı çerçeveli kurban sunuları ve festivaller gibi uygulamaları doğurmuştur. Bu uygulamalar Orişalarla iletişim kurma, kurban sunusu, yardım ve rehberlikleri için teşekkür ya da saygıyla yüceltme şeklindedir. Oduduva'nın Yoruba yaşam alanının başka yerlerinde de uygulamaları vardır. Ancak İle-İfe her şeyin merkezi olduğu için en önemlisidir. İletişim kurulan Orişaya ilişkin dileklerin ve beklentilerin bir karşılığı, ona karşı iyi olduğunu gösterme biçimi olan kurban sunuları, canlı ve cansız olmak üzere çeşitlidir. Kola fıstığı (olojumerin), tavuk ve lapa gibi şeyler sunulardan bazısıdır. ${ }^{63}$

Yoruba yaşam alanında İle-İfe, festivaller ve sanat ile de kendini göstermektedir. Örneğin Olojo Oduduva festivali, Orişaların Yoruba topraklarına yolculuk efsanesini konu edinmektedir. Buna göre Ogun Orişalara önderlik etmiş ve hedeflerine ulaşmalarını sağlamıştır. Bir savaşçı olarak İlegun İle-İfe halkı için savaşmış ve onların evrendoğumlarını gerçekleştirmiştir. Olojo ritüelleri de İle-İfe'nin varoluşu ve bir savaşçı kral olan Oranmiyan ile ilişkilidir. ${ }^{64}$ Olojo festivalinde İle-İfe kralının (Oonisinin) yaptığı bir uygulama; krallık, Orişalar, Olodumare ve İle-İfe ilişkisinin önemini gösterir niteliktedir. Buna göre festival İle-İfe Oonisinin tek başına beş günlük inzivaya çekilmesiyle başlar. Ooni, mührün koruyucusu olarak yılda bir defa taktığı efsanevi Are tacının bulunduğu odanın bitişiğindeki odada tam bir inzivaya çekilir. Bu süreçte eşleri, çocukları, arkadaşları, halk ya da saray hizmetçileriyle konuşmaz, ne yer ne de içer. Yalnızca Orişalarla iletişim kurup Yorubalar ve Nijerya için barış, güvenlik ve istikrar için bazı geleneksel ritleri gerçekleştirir. 65

Oduduva'nın Olojo festivalinde okunan şu şiiri Yorubaların İle-İfe'ye yükledikleri anlamları ortaya koymada iyi bir örnektir:

\footnotetext{
“İle-İfe, yeryüzünün beşiği

Yorubaların babası Oduduva'nın şehri

Bizi İle-İfe için yaratan Tanrı
}

\footnotetext{
Abiodun J. Macaulay, "Ritual as Theatre: An Analysis of Oduduwa Festival in Ikoro-Ekiti", Language in India, 15/8 (2015): 71-79.

64 Akinyemi Yetunde Blessing, "The Influence of the Kingship Institution on Olojo Festival in Ile-Ife: A Case Study of the Late Ooni Adesoji Aderemi", Africology: The Journal of Pan African Studies, 12/1 (2018): 483.

65 David O. Ogungbile, "Seclusion", ed. Molefi Kete Asante ve Ama Mazama, Encyclopedia of African Religion (California: SAGE Publications Ltd., 2009), 599.
} 


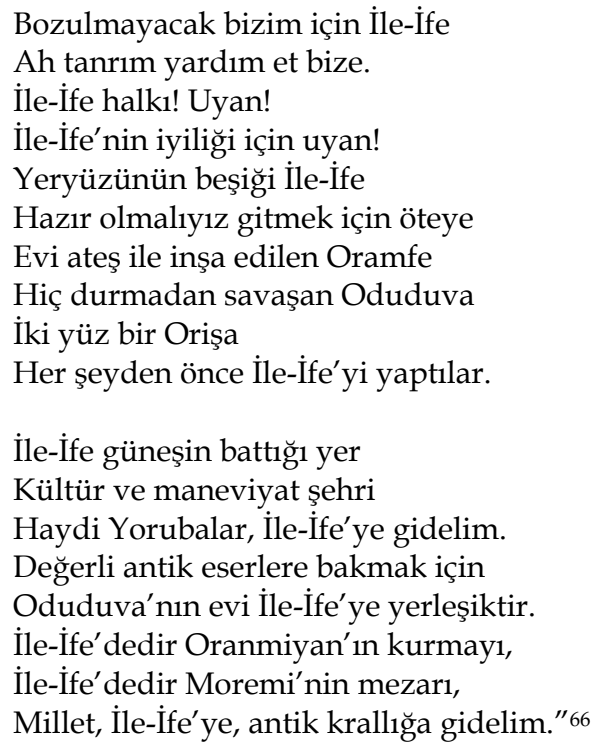

İle-İfe kült gruplarının çoğu, kendi festivalleri olmayanlar da dahil, İleİfe' nin yeni yıl festivali olan İtapa festivalinin çeşitli kültürel etkinliklerine bir şekilde katılım gösterirler. Ancak, kült grupları kesin olarak iki büyük partiye bölünmüş durumdadır. Biri Obatala ya da onun rahipleri öncülüğündedir, diğeriyse Oduduva. Örneğin, Obameri rahipleri Obatala'ya karşı kendi rakip festivallerini düzenlemelerine karşın kendi Orişalarının takipçisi olması nedeniyle yüksek Oduduva rahibine karşı bağlı hareket ederler. ${ }^{67}$ Bu noktada, İle-İfe' den sürülen Obatala'yla İle-İfe' de krallığı kuran Oduduva arasındaki mitolojik gerilimin uygulamalara yansıdığı, dolayısıyla İle-İfe'de Obatala'ya karşı Oduduva'ya gösterilenden daha az sitayiş gösterildiği anlaşılmaktadır.

İle-İfe festivallerinden olan Edi Festivali, Yoruba sözlü geleneğinde yer tutmuş Moremi'yle ilgilidir. Moremi, İle-İfe' deki halkını XIV. yüzyıldan bir süre önce İgboların saldırılarından kurtarmış ve çekiciliği ve zekâsıyla ünlenmiş bir kadın kahramandır. İgbo savaşçılarının ele geçirdiği Moremi onların ellerinden kurtulmuş, yaktığı ateşlerle işaret göndererek İgbo savaşçılarının saldırısını önceden halkına bildirmiş, böylece İle-İfe halkının kurtuluşunu sağlamıştır. Bunun üzerine Yoruba Orişaları, tek oğlu Oluorogbo'yu nehir Orişası Eşinmirin'e kurban etmesini istemişlerdir. Edi

66 Akinyemi Yetunde Blessing, "A Comparative Analysis of Olojo Festival under the Late Adesoji Aderemi and the Late Okunade Sijuwade Olubuse II", Africology: The Journal of Pan African Studies, 12/1 (2018): 12.

67 Dierk Lange, "The Dying and rising god in the New Year festival of Ife", Ancient Kingdoms of West Africa: African-Centred and Canaanite-Israelite Perspectives, (Dettelbach: Verlag J. H. Röll GmbH, 2004), 350. 
festivali bunun anısına ve onuruna kutlanmaktadır. Yedi gün süren Edi festivalinin önemli bir parçası olan davul çalma tabudur. ${ }^{68}$

İle-İfe bu tarihsel ve dinî önemini sanatsal alanda da göstermiştir. Arkeolojik verilere göre miladi 950-1400 tarihlerine ait heykel, insan kafas1 gibi buluntular, İle-İfe ve çevresindeki Yoruba medeniyetine ait olduğunu açıkça ortaya koymaktadır. Bunlar İle-İfe'nin insan yaşamının merkezi olduğunu gösteren yaratılış mitini ve insanlığın ve İle-İfe krallığının köken mitini destekler mahiyettedir. Bu hususu, krallık soy çizgisinin bugüne kırılmadan gelmesi de kanıtlamaktadır. ${ }^{69}$ Bunlar, mitolojide ve Yoruba dinî yaşamında olduğu gibi İle-İfe' nin merkezîliğini kültürel ve sanatsal alanda da ortaya koyduğunu göstermektedir.

\section{Sonuç}

Geleneksel Yoruba Dininde yaratılışın ve dünyanın merkezi kabul edilen veya bu özellikleri taşıyan İle-İfe'nin merkez simgeciliğinin hemen bütün unsurlarına sahip olduğu görülmüştür. Bunu hem çok zengin olan Yoruba sözlü geleneğinde hem de mitolojinin bir uyarlaması konumunda olan Yoruba gündelik yaşamında görmek mümkündür.

Mitolojiye göre İle-İfe; Olodumare'nin görevlendirdiği Orişaların göksel âlemden primordiyal suya inerek evrenin ve insanın yaratılışını gerçekleştirdikleri yerdir. Aynı zamanda yeryüzünün ilk mekânı olan İleİfe'nin tanrısal hakimiyetin tecelli ettiği ve böylelikle krallığın merkezi sayıldığı bir merkeze işaret etmesi önemlidir. Nitekim yaratılışın, insanın ve hayat ağacının var edildiği merkezdir. Böylelikle İle-İfe mitolojiyle insan yaşamının, tanrısal âlemle insan âleminin, gökle yeryüzünün kesiştiği yer haline dönüşmektedir. Hem yaratılışın hem dünyanın merkezi olan İle-İfe, herşeyin kendisine kilitlendiği merkez olup gök, yer ve yeraltının kesişme noktasıdır. Tanrısal âleme ve kutsallaşmaya açılan kapı olarak takdim edilen İle-İfe, yer-gök ekseninin merkezi olduğuna işaret eder. Bu sebeple dünyanın en kutsal yeri olarak tanrısal âleme açılan kapı ve ibadetin (ritüel, sunu, dualar vb.) merkezi olarak ölümlü âlemden ölümsüzlük âlemine yükselişi, yücelmeyi sembolize eder.

İle-İfe, Yoruba halkı için birçok yönden değerli ve kutsaldır. Orişaların ilk ayak bastığı, Orişalar tarafından inşa edilen, insanoğlunun yaratıldığı,

\footnotetext{
68 Toyin Falola ve Ann Genova, Historical Dictionary of Africa, ed. Jon Woronoff (Toronto: The Scarecrow Press, Inc., 2009), 234.

69 Anda, Yoruba, 17-18.
} 
insanlığın yayıldığı ve kutsal krallığın kurulduğu merkezdir. Krallık soyunun ve Yoruba halkının beşiği, yaratılışın ve dünyanın merkezi olması söz konusudur. Mitolojinin yaşama yansıdığı noktada temel ibadet merkezi olması yanında Yoruba tarihi, sanatı ve kültüründe önemli bir yeri vardır. İnanılanın somut ispatı niteliğinde arkeolojik kalıntıların ve tanrısal krallığın soyunun çizgisinden sapmaksızın bugüne gelmesi merkez simgeciliğinin yaşatıldığını ortaya koymada yeterlidir.

\section{Kaynakça}

Anda, Michael O. Yoruba. New York: Rosen Pub. Group, 1996.

Anderson/Sankofa, David A. "The Golden Chain". Creation Stories from around the World Encapsulations of some traditional stories explaining the origin of the Earth, its life, and its peoples, ed. Bruce Railsback, Word Edition., 23-24. Georgia: University of Georgia, 2000.

Apter, Andrew. "The Historiography of Yoruba Myth and Ritual". History in Africa 14 (1987): 1-25.

Asante, Molefi Kete. "Ile-Ife". Ed. Molefi Kete Asante ve Ama Mazama. Encyclopedia of African Religion, 336. California: SAGE Publications Ltd., 2009.

"Orisha-Nla". Ed. Molefi Kete Asante ve Ama Mazama. Encyclopedia of African Religion, 507-8. California: SAGE Publications Ltd., 2009.

Badejo, Diedre L. “Orunmila”. Ed. Molefi Kete Asante ve Ama Mazama. Encyclopedia of African Religion, 507-8. California: SAGE Publications Ltd., 2009.

Bibeli Bible of Yoruba People Children of The Good Morning. The University of African Art Press Electronic Book Media, 2007.

Blessing, Akinyemi Yetunde. "A Comparative Analysis of Olojo Festival under the Late Adesoji Aderemi and the Late Okunade Sijuwade Olubuse II". Africology: The Journal of Pan African Studies 12, sy. 1 (2018): 8-20.

. "The Influence of the Kingship Institution on Olojo Festival in Ile-Ife: A Case Study of the Late Ooni Adesoji Aderemi". Africology: The Journal of Pan African Studies 12, sy. 1 (2018): 482-98.

Courlander, Harold. Tales of Yoruba Gods and Heroes. New York, Crown Publishers, 1973.

"Creation Stories from Around the World Afro-Carribean Yoruba, unknown origins1989 CE Mythology of the Yoruba Religion A recounting and explanation of Yoruba creation stories by Oba Ecun, the Yoruba name of Cuban-born Cecilio Perez, Yoruba practitioner and scholar. Text and notes taken from Ita: Mythology of the Yoruba Religion, by Oba Ecun, Obaecun Books, Miami 1989." Dhwtys Learning Center, PDF Edition, 2018.

Eliade, Mircea. İmgeler Simgeler. Çev. Mehmet Ali Kılıçbay. Ankara: Gece Kitapları, 1992.

. Mitlerin Özellikleri. Çev. Sema Rifat. İstanbul: Om Yayınları, 2001.

Falola, Toyin ve Ann Genova. Historical Dictionary of Africa. Ed. Jon Woronoff. Toronto: The Scarecrow Press, Inc., 2009.

Idowu, E. Bolaji. Olodumare: God In Yoruba Belief. London: Longmans, 1962. 
Karenga, Maulana. "Oduduwa". Ed. Molefi Kete Asante ve Ama Mazama. Encyclopedia of African Religion, 474-75. California: SAGE Publications Ltd., 2009.

Khan Academy. "Kingdom of Ife: Sculptures from West Africa”. Erişim: 15 Ekim 2019. https://www.khanacademy.org/humanities/art-africa/westafrica/nigeria/a/kingdom-of-ife-sculptures-from-west-africa.

Laitin, David D. Hegemony and Culture: Politics and Change Among the Yoruba. Chicago: University of Chicago Press, 1986.

Lange, Dierk. "Ife and the Origin of the Yoruba: Historigraphical Considerations". Ife: Annals of the Institute of Cultural Studies 6 (1995): 39-49.

. "The Dying and rising god in the New Year festival of Ife". Ancient Kingdoms of West Africa: African-Centred and Canaanite-Israelite Perspectives, 343-75. Dettelbach: Verlag J. H. Röll GmbH, 2004.

Law, R. C. C. "The Heritage of Oduduwa: Traditional History and Political Propaganda among the Yoruba". The Journal of African History 14, sy. 2 (1973): 207-22.

Macaulay, Abiodun J. "Ritual as Theatre: An Analysis of Oduduwa Festival in IkoroEkiti". Language in India 15, sy. 8 (2015): 64-89.

Neimark, Philip John. The Way of The Orisa: Empowering Your Life Through The Ancient African Religion of Ifa. San Francisco: Harper Collins Publishers, 1993.

Obayemi, Ade. "Ancient Ile-Ife: Another Cultural Historical Reinterpretation". Journal of the Historical Society of Nigeria 9, sy. 4 (1979): 151-85.

Ogundayo, BioDun J. “Yoruba”. Ed. Molefe Kete Asente ve Ama Mazama. Encyclopedia of African Religion, 738-39. California: SAGE Publications Ltd., 2009.

Ogungbile, David O. "Seclusion". Ed. Molefi Kete Asante ve Ama Mazama. Encyclopedia of African Religion, 597-601. California: SAGE Publications Ltd., 2009.

Ogunyemi, Yemi D. Introduction to Yoruba Philosophy, Religion and Literature. New York: Athelia Henrietta Press, 1998.

Ojuade, J. 'Sina. “The Issue of 'Oduduwa' in Yoruba Genesis: the Myths and Realities". Transafrican Journal of History 21 (1992): 139-58.

Olupona, Jacob K. City of 201 Gods: Ilé-Ife in Time, Space, and the Imagination. Los Angeles: University of California Press, 2011.

Omisore, Emmanuel Olufemi, Ime Johnson Ikpo ve Godwin Ehis Oseghale. "Maintenance Survey of Cultural Properties in Ile-Ife, Nigeria". Journal of Building Appraisal 4, sy. 4 (Mart 2009): 255-68.

Peel, J. D.Y. Religious Encounter and The Making of The Yoruba. Bloomington \& Indianapolis: Indiana University Press, 2003.

Rogers, Ibram H. “Obatala”. Ed. Molefi Kete Asante ve Ama Mazama. Encyclopedia of African Religion, 470-72. California: SAGE Publications Ltd., 2009.

Seyfeli, Canan ve Elif Kul. "Geleneksel Yoruba Dininde Yaratılış ve Ölüm Sonrası Hayat". Sosyal Bilimler Araştırma Dergisi 16, sy. 32 (2018): 237-72.

“Olodumare/Olorun: Geleneksel Yoruba Dininde Yüce Tanr1". Sosyal Bilimler Araştırma Dergisi 17, sy. 33 (2019): 15-42.

Sogoba, Mia. "Ile-Ife: The Sacred Yoruba City". Cultures of West Africa, 14 Ocak 2019. https://www.culturesofwestafrica.com/ile-ife-sacred-yoruba-city/. 
Ushe, Ushe Mike. "God, Divinities and Ancestors in African Traditional Religious Thought". Igwebuike: An African Journal of Arts and Humanities 3, sy. 4 (2017): 154-79.

Wariboko, Nimi. "The King's Five Bodies:: Pentecostals in the Sacred City and the Logic of Interreligious Dialogue". Journal of Africana Religions 2, sy. 4 (2014): 477-501. 
Doi: 10.34247/artukluakademi.638802

\title{
Canan Seyfeli
}

\author{
Ile-Ife: The Center of Creation and the World in Traditional Yoruba Religion \\ Citation/(-): Seyfeli, Canan, Ile-Ife: The Center of Creation and the World in \\ Traditional Yoruba Religion, Artuklu Akademi 2019/6 (2),229-252.
}

\section{Extended Abstract}

The subject of the study is Ile-Ife as a religious center. The subject has been studied as a central role in mythology and the Yoruba habitat. When the products of mythology and other oral traditions are compared with the activities taking place in Ife, it is seen that myth and lle-Ife overlap. The believed truth and the lived fact complement each other. Ile-Ife, where the creation took place, has also been the center of lle-Ife. In fact, it is the center that brings together heaven and earth, the visible realm and the invisible realm, the people and the Orishas and the Supreme God Olodumare. It is the transition of man into a divine world by becoming sacred in the holy city. The aim of this study is to reveal the reality of this unification and transformation in mythology and Ile-Ife.

In this study, it was seen that Ile-Ife has almost all the elements of the center symbolism. This can be seen both in the very rich Yoruba oral tradition and in the daily Ile-Ife of Yoruba, which is an adaptation of mythology.

According to mythology, Ile-Ife is the place where the Orishas assigned by Olodumare descend from the celestial realm to the primordial water. The Orishas descend with the golden chain and realize the creation of the universe and man at this point. The three Orishas (Obatala, Orunmila and especially Oduduwa), which were active in creation, were also important in the living space of Yoruba, which was centralized in Ife. Creation began with soil scattered in water. The starting point of Ile-Ife is also accepted as the center. This is also the point of human creation. Creation in the mind of Yoruba means the beginning of their universe and themselves. Obatala is responsible for shaping human beings. The expansion of the place, which started from Ifa-Vara in Ile-Ife, is the task of Orunmila in one myth, and Oduduwa in another. For this reason, Yorubas called Ile-Ife "the house of Orunmila". However, Oduduwa has occupied much more space in Yoruba lle-Ife. Oduduwa is both primordial and ancestral to Orisha. He is the first ancestor of the Yoruba people, that is humanity, so Ile-Ife is the starting point of humanity. He is also the first king, and Ile-Ife is the center of the kingdom. The center of the Ile-Ife is Ifa-Vara where the Tree of Ile-Ife is planted by the Orishas. This is the place where the royal palace is located and the heart of Ile-Ife, called Enuva. Ile-Ife, the cradle of humanity, also has an important place in the history, art and culture of Yoruba.

Ile-Ife is the intersection of mythology and human lle-Ife, the divine realm and the human realm and the sky and the earth. Ile-Ife, the center of both creation and the world, is the center where everything is locked into itself. Ife is the intersection point of the sky, earth and underground. The Tree of Ile-Ife planted 
here in creation is the axis of these three. Ile-Ife is the gate of the heavens. Through this gate Orishas landed in the realm of the earth and started creation. The fact that everything on on the earth has a starting point starting point, that all the roads get there, is about the different aspects of being an axis. For this reason, Ile-Ife is the gateway of the earth to the skies.

The Yorubas perform the basic Orisha worship in Ile-Ife. Fort hem Ife is is the most sacred place in the world, the gateway to divine realization and sanctification. Worshipping there is important. Ife priests perform the only ritual of worshiping Olodumare there. The Tree of Ile-Ife planted by the Orishas symbolizes ascension from the mortal realm to the realm of immortality. Therefore, there are temples dedicated to the important Orishas in Ile-Ife. Especially Oduduwa temple, which stands in the center of Ile-Ife, is the most important. Other temples are lined around Oduduwa's. The Yorubas have devoted themselves to one or more Orishas to worship in their daily lives. For them, their Orishas are more important, and the festivals, rituals, presentations and prayers dedicated to them are fundamental worship. However, although there are many Orishas with a temple in Ile-Ife, all Yorubas participate in the practices directly related to Ile-Ife and show particular loyalty to Oduduwa. The Yorubas see themselves as the chisldren of their Orisha. But Oduduwa is different, because the sacred text Odu Ifa has defined the people (Yorubas) as the children of Oduduwa. 